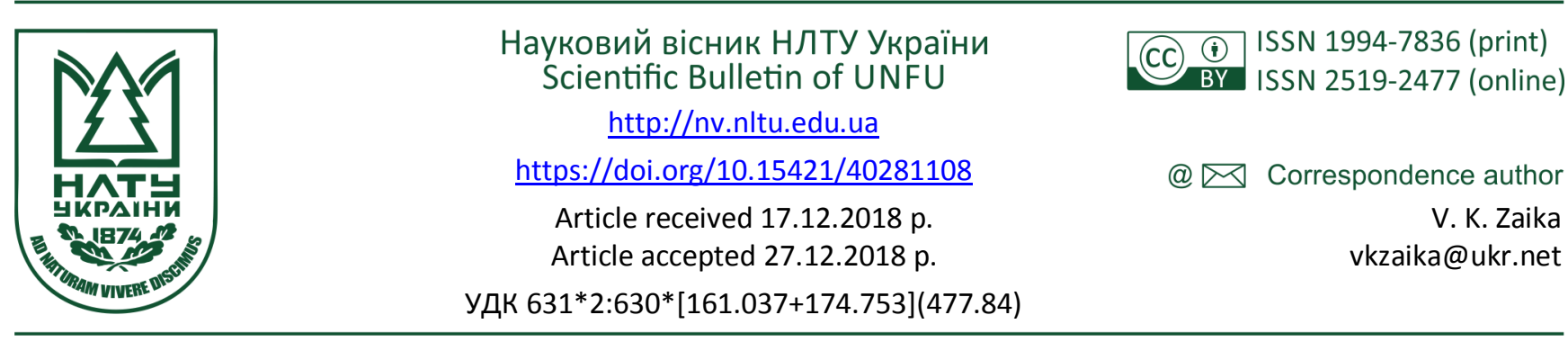

Е. І. Керімов ${ }^{1}$ В. К. Заїка ${ }^{2}$

${ }^{1}$ Кременечький лісотехнічний коледж, с. Білокриниия, Украйна ${ }^{2}$ Начіональний лісотехнічний університет України, м. Львів, Україна

\title{
БІОЕЛЕКТРИЧНІ ПОТЕНЦІАЛИ МОДРИНИ ЄВРОПЕЙСЬКОЇ В ДЕРЕВОСТАНАХ
} КРЕМЕНЕЦЬКОГО ГОРБОГІР'Я

\begin{abstract}
Досліджено біоелектричні потенціали модрини європейської, дуба звичайного, ялини європейської і сосни звичайної, які формують деревостани в різних типах лісорослинних умов Кременецького горбогір'я. Вік деревостанів становить $12-$ 109 років. Частка модрини в їх складі змінюється в межах 1-10 одиниць. Модрина європейська в умовах суборів і сугрудів характеризується нижчими абсолютними показниками БЕП кореневої шийки, порівняно з сосною звичайною, а в умовах грудів - вищими, порівняно з дубом звичайним і ялиною європейською. Встановлені відмінності між деревними видами зберігаються упродовж дня. Відмінності між модриною і дубом за абсолютними показниками біопотенціалів посилюються у другій половині дня. У модрини в мішаних молодняках і середньовікових деревостанах абсолютні значення БЕП виявились вищими, ніж у чистих деревостанах. Встановлено три типи денних біопотенціалограм, які характеризують динаміку проходження метаболічних процесів у деревних видів у деревостанах різних лісорослинних умов та видового складу. Між біометричними показниками модельних дерев різних деревних видів і середньоденними показниками біопотенціалів переважно спостережено помірний і значний прямий кореляційний зв'язок. Більш тісною залежність денної зміни біопотенціалів виявлено від денної динаміки температури і вологості повітря, аніж від інтенсивності світла. Між вологістю повітря і біоелектричними потенціалами існує зворотний кореляційний зв'язок.
\end{abstract}

Ключові слова: біоелектричні потенціали; модрина європейська; деревостан; денні біопотенціалограми; кореляційний зв'язок.

Вступ. Ріст і формування деревостанів є інтегральним показником процесів життєдіяльності деревних видів. Інтенсивність життєвих процесів у рослин добре характеризують біоелектричні потенціали (БЕП) (Zaika, Kerimov \& Ivanytskyi, 2016; Kipkore \& Maksimov, 1988; Kolovskii, 1980; Kolovskii, 1973, 1984). Інтенсивність проходження життєвих процесів у деревних видів з однієї сторони характеризується внутрішніми генетично детермінованими чинниками (Krinitckii, 1990; Krinitckii \& Bondarenko, 1984), а 3 іншої - зовнішніми умовами (Rutkovskii, 1973; Salna, 1964; Shevernozhuk, 1968). 3 огляду на це, біоелектричні потенціали використовують для виявлення дерев високої життєвості та інтенсивності росту (Zaika, Kerimov \& Ivanytskyi, 2016; Kolovskii, 1980, 1990; Krinitckii \& Bondarenko, 1984; Krynytskyi, 1993; Krynytskyi \& Zaika, 1995; Krynytskyi, 1992; Rybak \& Zaika, 2013), успадкування інтенсивності проходження метаболічних процесів півсібсовим потомством (Krinitckii, 1990; Krinitckii \& Bondarenko, 1984), стану дерев, уражених шкідниками і фітопатогенами (Rutkovskii, 1965; Rutkovskii \& Kishenkov, 1980). Вплив особливостей формування деревостану на біоелектричну активність дерев розглянуто тільки в окремих робоTax (Krinitckii, 1984; Krinitckii \& Bondarenko, 1984; Rutkovskii \& Kishenkov, 1980). Так, Р. Г. Шеверножук (Kri-

nitckii, 1990) і Ю. А. Азнієв, І. Е. Ріхтер і У. В. Сарнацкі (Rutkovskii \& Kishenkov, 1980) виявили тісний кореляційний зв'язок між показниками біопотенціалів із класом росту дерев у ялинових деревостанах. Особливості проходження денних змін біоелектричних потенціалів у дерев сосни різної інтенсивності росту 8-річних півсібсових потомств з огляду на формування ними деревостанів розглянуто в роботі Г. Т. Криницького й В. К. Заїки (Krinitckii \& Bondarenko, 1984). Вони встановили, що величина біоелектричних потенціалів дерев та їхні зміни в денній динаміці залежать від ступеня посилення конкурентної боротьби і диференціації особин у деревостанах. Значні відмінності у величині біоелектричної активності в денному і сезонному ритмах 8-річних тополь різного фізіологічного стану встановив І. В. Рутковський (Rybak \& Zaika, 2013).

Необхідно зазначити, що останнім часом дослідження особливостей формування деревостанів та встановлення інтенсивності життєдіяльності деревних видів із використанням біоелектричних потенціалів майже не проводять. Тому наші дослідження спрямовані на розвиток вчення про взаємовідносини деревних видів у деревостанах.

Об'єктом дослідження є інтенсивність функціонування деревних видів у деревостанах за участю модри-

\section{Інформація про авторів:}

Керімов Ельхан Ілхамович, викладач, кафедра лісівництва. Email: elhan26@rambler.ru

Заїка Володимир Костянтинович, д-р біол. наук, професор, кафедра лісівництва. Email: vkzaika@ukr.net

Цитування за ДСтУ: Керімов Е. І., Заїка В. К. Біоелектричні потенціали модрини європейської в деревостанах Кременецького горбогір'я. Науковий вісник НлТУ України. 2018, т. 28, № 11. С. 42-47.

Citation APA: Kerimov, E. I., \& Zaika, V. K. (2018). Bioelectric potentials of european larch in the stands of the Kremenets hill area. Scientific Bulletin of UNFU, 28(11), 42-47. https://doi.org/10.15421/40281108 
ни європейської в умовах Кременецького горбогір'я.

Предмет дослідження - біоелектричні потенціали модрини європейської, дуба звичайного, сосни звичайної і ялини європейської в деревостанах різного породного складу та лісорослинних умов.

Мета дослідження - встановити особливості життєдіяльності модрини європейської та інших деревних видів у деревостанах різного віку, видового складу та лісорослинних умов.

Дослідження проводили в деревостанах за участю модрини європейської віком 12-109 років, які ростуть в умовах від бідних суборів до свіжих і вологих грудів Кременецького горбогір'я. Частка модрини в їх складі становить від 1-ї до 10-ти одиниць. Серед них переважають деревостани 3 часткою модрини 5-8 одиниць. Вони ростуть за II - $\mathrm{I}^{\mathrm{d}}$ класами бонітету (Aznieu, Rykhter \& Sarnatski, 1984).

Біоелектричні потенціали сосни звичайної вивчали за методикою Г. Т. Криницького (Zaika, Kerimov \& Ivanytskyi, 2016; Kipkore \& Maksimov, 1988). Для вимірювання БЕП використовували високоомний біопотенціалметр і неполяризаційні хлорсрібні електроди. Вимірювання денної динаміки біопотенціалів у дерев прово- дили на рівні кореневої шийки відносно Землі в безхмарну або малохмарну погоду. Для проведення дослідження у деревостані ми підбирали по 10-20 модельних дерев кожного виду різної інтенсивності росту (швидко-, середньо- і повільнорослі) та вимірювали їх висоту і діаметр.

Результати дослідження. Особливості формування деревостанів та взаємовідносини між деревними видами зумовлюють інтенсивність проходження у дерев життєвих процесів. Найважливішим чинником є конкурентні взаємовідносини, які по-різному проявляються на різних етапах формування деревостанів. Найбільше вони виявляються в молодняках, що призводить до значного пригнічення життєвих процесів у відсталих у рості дерев та їх відпаду ще до переходу до категорії середньовікових деревостанів. У мішаних деревостанах на функціонування дерев впливає внутрішньовидова i міжвидова, а в чистих - тільки внутрішньовидова конкуренція. Для встановлення ступеня взаємовпливу деревних видів у деревостанах за участю модрини європейської ми використали біоелектричні потенціали. Середньоденні показники БЕП деревних видів дослідних деревостанів наведено в табл. 1.

Табл. 1. Середньоденні показники біоелектричних потенціалів деревних видів у деревостанах за участю модрини свропейської (серпень 2015 р.)

\begin{tabular}{|c|c|c|c|c|c|c|c|}
\hline \multirow{2}{*}{$\begin{array}{c}\text { № пр. } \\
\text { пл. }\end{array}$} & \multirow{2}{*}{ Склад деревостану } & \multirow{2}{*}{$\begin{array}{c}\text { Вік, } \\
\text { років }\end{array}$} & \multirow{2}{*}{ Деревний вид } & \multicolumn{4}{|c|}{ Показник } \\
\hline & & & & $M \pm m$ & $\%$ & $t_{\phi}$ & $V, \%$ \\
\hline \multicolumn{8}{|c|}{ Молодняки } \\
\hline 13 & 10Мдє+КлгКлясАкбОс & 14 & Мдє & $-65,0^{ \pm 1,8}$ & 100,0 & 0,00 & 15,1 \\
\hline \multirow{2}{*}{15} & \multirow{2}{*}{ 9Мдє1Сз } & \multirow{2}{*}{25} & Мдє & $-54,4^{ \pm 5,3}$ & 83,7 & 1,89 & 42,6 \\
\hline & & & $\mathrm{C}_{3}$ & $-73,2^{ \pm 6,1}$ & - & - & 30,2 \\
\hline \multirow{2}{*}{14} & \multirow{2}{*}{$8 \mathrm{Mдє2С} 2$ +Чш } & \multirow{2}{*}{29} & Мдє & $-45,7^{ \pm 2,5}$ & 70,3 & 6,27 & 25,6 \\
\hline & & & $\mathrm{C}_{3}$ & $-56,2^{ \pm 5,2}$ & - & - & 30,5 \\
\hline \multirow{2}{*}{6} & \multirow{2}{*}{ 10Мдг+ЯлєЯсзБпГз } & \multirow{2}{*}{12} & Мдг & $-77,5^{ \pm 2,7}$ & 119,2 & 3,85 & 14,9 \\
\hline & & & Ялє & $-67,0^{ \pm 2,9}$ & - & - & 18,4 \\
\hline \multicolumn{8}{|c|}{ Середньовікові та перестиглі } \\
\hline 2 & 9Мє1Кля+КлгБпГз & 52 & Мде & $-71,8^{ \pm 2,2}$ & 100,0 & 0,00 & 13,6 \\
\hline 8 & 7Мдє3Ясз+ДзГзКлг ВзгЛпд & 56 & Мдє & $-74,7^{ \pm 1,9}$ & 104,0 & 1,00 & 12,2 \\
\hline 10 & 8Дч1Мдє1Бкл+КляЯсзГзВзгЛпд & 46 & Мдє & $-76,4^{ \pm 3,3}$ & 106,4 & 1,16 & 18,5 \\
\hline \multirow{2}{*}{7} & \multirow{2}{*}{ 3Мдє3Гз1Дз1Ясз1 Дч1Взг+КлгЛпдБп } & \multirow{2}{*}{52} & Мде & $-74,4^{ \pm 2,7}$ & 103,6 & 0,75 & 12,1 \\
\hline & & & Д3 & $-91,1^{ \pm 3,4}$ & - & - & 12,8 \\
\hline \multirow{2}{*}{1} & \multirow{2}{*}{ 5Мє2Ясз1Дз1Кля1Бха+КлгВзгГз } & \multirow{2}{*}{58} & Мдє & $-78,2^{ \pm 2,1}$ & 108,9 & 1,84 & 12,7 \\
\hline & & & Д3 & $-60,3^{ \pm 3,0}$ & - & - & 17,4 \\
\hline \multirow[t]{2}{*}{9} & \multirow{2}{*}{ 7Мдє1Ялє1Ясз1Клг+ВзгЛпдГз } & \multirow{2}{*}{60} & Мдє & $-87,0^{ \pm 3,4}$ & 121,2 & 3,75 & 16,9 \\
\hline & & & Ялє & $-57,4^{ \pm 8,5}$ & - & - & 36,0 \\
\hline \multirow{2}{*}{16} & \multirow{2}{*}{ 7Мдє2Ясз1ДзБкл+КлгКляВзг } & \multirow{2}{*}{101} & Мде & $-59,3^{ \pm 2,2}$ & 82,6 & 4,02 & 17,1 \\
\hline & & & Д3 & $-52,7^{ \pm 7,3}$ & - & - & 30,9 \\
\hline \multirow{2}{*}{3} & \multirow{2}{*}{ 8Мдє1ДзЯсз1Гз+Клг } & \multirow{2}{*}{109} & Мдє & $-48,6^{ \pm 3,6}$ & 67,7 & 5,50 & 29,4 \\
\hline & & & Д3 & $-35,1^{ \pm 5,2}$ & & & 51,3 \\
\hline
\end{tabular}

Примітки: 1. Мдє - модрина європейська, Мдг - модрина гібридна, Сз - сосна звичайна, Дз - дуб звичайний, Дч - дуб червоний, Ясз - ясен звичайний, Бкл - бук лісовий, Ялє - ялина європейська, Клг - клен гостролистий, Кля - клен-явір, Кляс - клен ясенелистий, Лпд - липа дрібнолиста, Чш - черешня, Взг - в'яз голий, Бха - бархат амурський, Гз - граб звичайний, Ос - осика, Бп - береза повисла, Акб - акація біла. 2. Табличне значення t-критерію Ст'юдента становить 2,18.

3 табл. 1 видно, що в молодняків (пр. пл. 13, 14, 15) середньоденні показники БЕП кореневої шийки модрини європейської становлять $-45,7--65,0 \mathrm{MB}$, а в модрини гібридної (пр. пл. 6) - -77,5 мВ. Зменшення абсолютних показників БЕП кореневої шийки модрини європейської в мішаних дослідних деревостанах на ділянках 14 і 15 відносно чистого (діл. 13) становить 16,3$29,7 \%$. Істотне зниження величини біопотенціалів у модрини спостерігали на ділянці $14\left(t_{\phi}=6,27 ; t_{05}=2,18\right)$. $\mathrm{У}$ сосни звичайної, яка росте в складі деревостанів на ділянках 14 і 15, абсолютні значення БЕП виявились вищими, ніж у модрини європейської на $23,0-34,5 \%$. Необхідно зазначити, що на ділянці 15 деревостан росте в умовах свіжого дубового субору, а модрина пере- вищує сосну за висотою і діаметром на 17,6-24,1\% (Aznieu, Rykhter \& Sarnatski, 1984). Модрина і сосна тут ростуть окремо. На половині площі цієї ділянки умови близькі до $A_{2}$, де модрина відпала і вона заросла сосною, а модрина вижила і росте на іншій частині ділянки 3 багатшим трофотопом. На пробній площі 14 в умовах свіжого грабово-дубового сугруду зі складом 29-річного деревостану $8 \mathrm{Mдє2С} 3+$ Чш сосна має природне походження і за висотою і діаметром не значно перевищує модрину на $1,1-10,8 \%$. Зазначені умови формування цих деревостанів і зумовили переважання біоелектричної активності сосни над модриною. Модрина гібридна за абсолютним показником БЕП істотно перевищуе модрину європейську $\left(t_{\phi}=3,85 ; t_{05}=2,18\right)$ і на $13,5 \%$ - 
ялину європейську, з якою вона формує деревостан (пр. пл. 6).

У середньовікових і перестиглих деревостанах середньоденні показники БЕП модрини європейської змінюються в межах $-48,6--87,0$ мВ, а дуба звичайного від -35,1 до -91,1 мВ. Встановлено, що у середньовікових деревостанів абсолютні показники біопотенціалів модрини виявились на 3,6-21,2 \% вищими за контроль. Істотне ж переважання БЕП модрини над контролем виявлено тільки на ділянці $9\left(t_{\phi}=3,75 ; t_{05}=2,18\right)$. У перестиглих 101-109-річних деревостанах спостерігаємо істотне, на $17,4-32,3 \%\left(t_{\phi}=4,02-5,50 ; t_{05}=2,18\right)$, зниження біоелектричної активності в модрини європейської відносно контролю. Необхідно зазначити, що біоелектрична активність модрини в переважної кількості середньовікових і перестиглих деревостанів виявилась вищою за дуба. Так, на ділянках 1, 3 і 16 абсолютні показники БЕП кореневої шийки модрини перевищували дуба на $12,5-29,7 \%$, а на ділянці 9 - ялину на $51,6 \%$. Тільки в деревостані на ділянці 7 БЕП кореневої шийки дуба виявилась на 22,4 \% вищою за модрину європейську. Очевидно на цій ділянці модрина зазнає значного фітоцено-
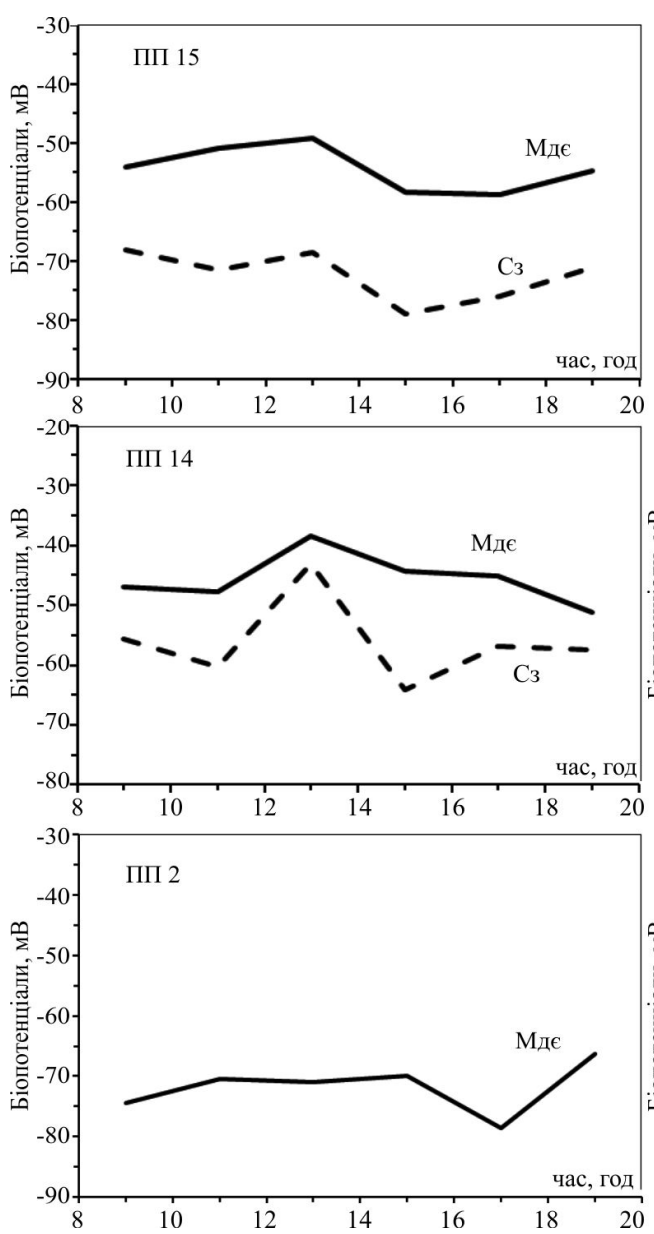

Рис. 1. Денна динаміка біоелектричних потенціалів кореневої ши

Денні зміни біопотенціалів інших деревних видів, які ростуть у деревостанах разом із модриною європейською, зазвичай не відрізняються від неї. Так, сосна звичайна в деревостанах на пр. пл. 14 і 15 упродовж всього дня характеризується вищою біоелектричною активністю від модрини європейської. Характер денних змін БЕП дуба звичайного на ділянках 3, 7 і 16 є подібним до модрини, а на пр. пл. 1 значно відрізняється від неї. На пр. пл. 1, починаючи 311 години і до кінця дня, абсолютні показники біопотенціалів модрини зроста- тичного впливу зі сторони ясена звичайного й дуба червоного. Її частка в складі цього деревостану становить 3 одиниці. В інших мішаних деревостанах модрина $\epsilon$ домінуючим видом із часткою у їх складі 5-9 одиниць.

Варіювання показників БЕП у модрини європейської є переважно середнім і тільки на ділянках 3, 14 i 15 - сильним. Дослідження денної динаміки біоелектричних потенціалів модрини й інших деревних видів показало на значні відмінності в характері проходження метаболічних процесів протягом дня. Ми встановили три типи біопотенціалограм модрини європейської (рис. 1). Так, у деревостанах на пр. пл. 1, 9, 10, 14 і 15 у модрини спостерігали незначне зниження абсолютних показників біопотенціалів у першій половині дня (до 11-13 години) та незначне їх зростання у другій його половині. У модрини в деревостанах на пр. пл. 8 і 13 виявлено стрімке зниження абсолютних значень БЕП до 11-13 години і потім різке зростання у другій половині дня. На ділянках 3, 7 і 16 у модрини європейської і на ділянці 6 у модрини гібридної БЕП кореневої шийки інтенсивно знижувались упродовж всього дня.
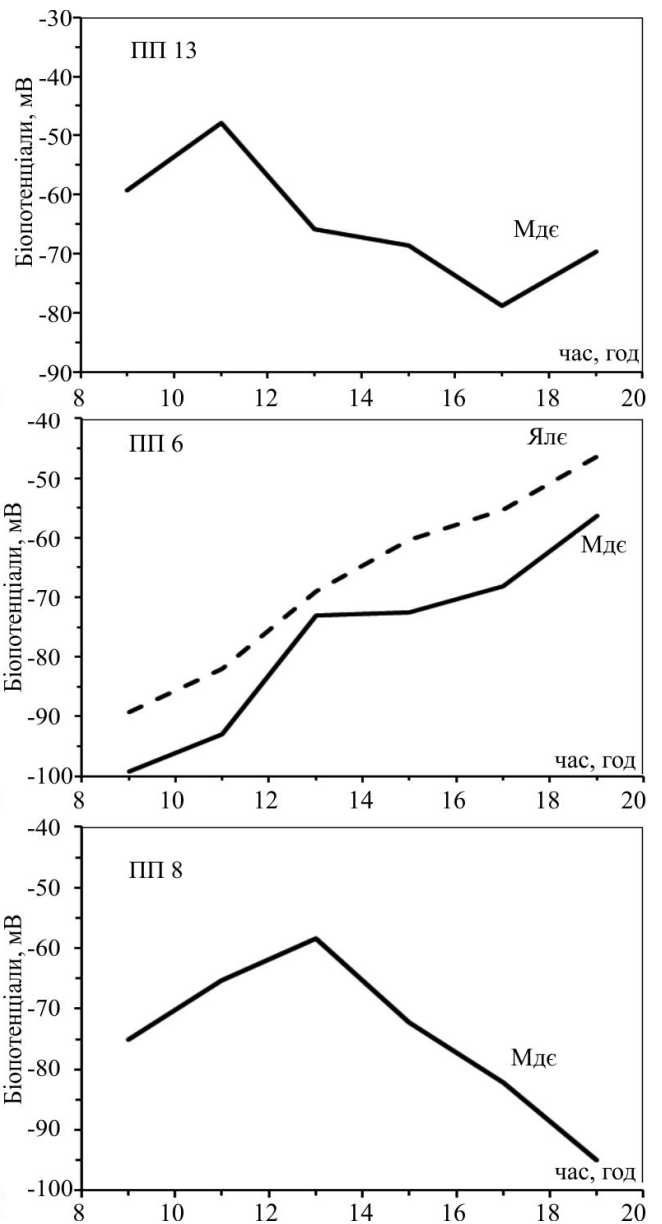

ють, а дуба зменшуються. Спільним для ділянок 1, 3 і $16 \epsilon$ збільшення відмінностей за величиною БЕП між модриною i дубом впродовж другої половини дня. Встановлено, що в дуба в другій половині дня інтенсивність життєвих процесів на цих ділянках знижується більш інтенсивно, ніж у модрини. Очевидно це зумовлено фітоценотичними особливостями взаємодії між деревними видами, які склалися у процесі формування деревостанів. Так, у деревостанах на ділянках 1, 3 i 16 склались більш значні відставання дуба за біомет- 
ричними показниками від модрини і ясена, ніж на ділянці 7 (Aznieu, Rykhter \& Sarnatski, 1984). У деревостані на ділянці 7 абсолютні показники БЕП кореневої шийки в дуба виявились вищими, ніж у модрини упродовж всього дня, але найбільшими вони були зранку і в першій половині дня.

Найбільші відмінності у проходженні функціональних процесів склались між модриною і ялиною європейською, які сформували 60-річний деревостан на ділянці 9. У ялини європейської істотне зниження біоелектричної активності відносно модрини європейської спостерігаємо впродовж всього дня (див. рис. 2).
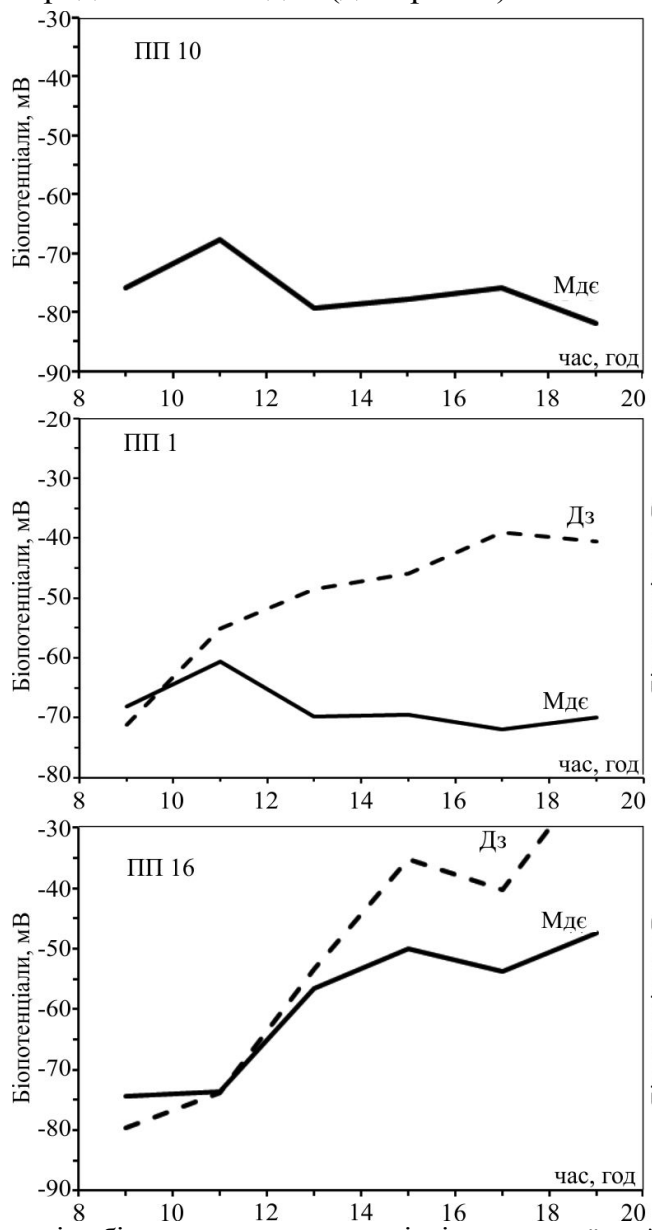

Біоелектричні потенціали рослин чутливо реагують на зміну мікрокліматичних чинників і особливо температури й освітленості (Rutkovskii, 1973; Salna, 1964; Shevernozhuk, 1968). В умовах фітоценозу на процеси життєдіяльності рослин значно впливають фітоценотичні умови, які, накладаючись на мікрокліматичні чинники, визначають біоелектричну активність деревних видів. Результати дослідження кореляційних зв'язків БЕП із біометричними показниками модельних дерев і мікрокліматичними показниками детально наведено в табл. 2.
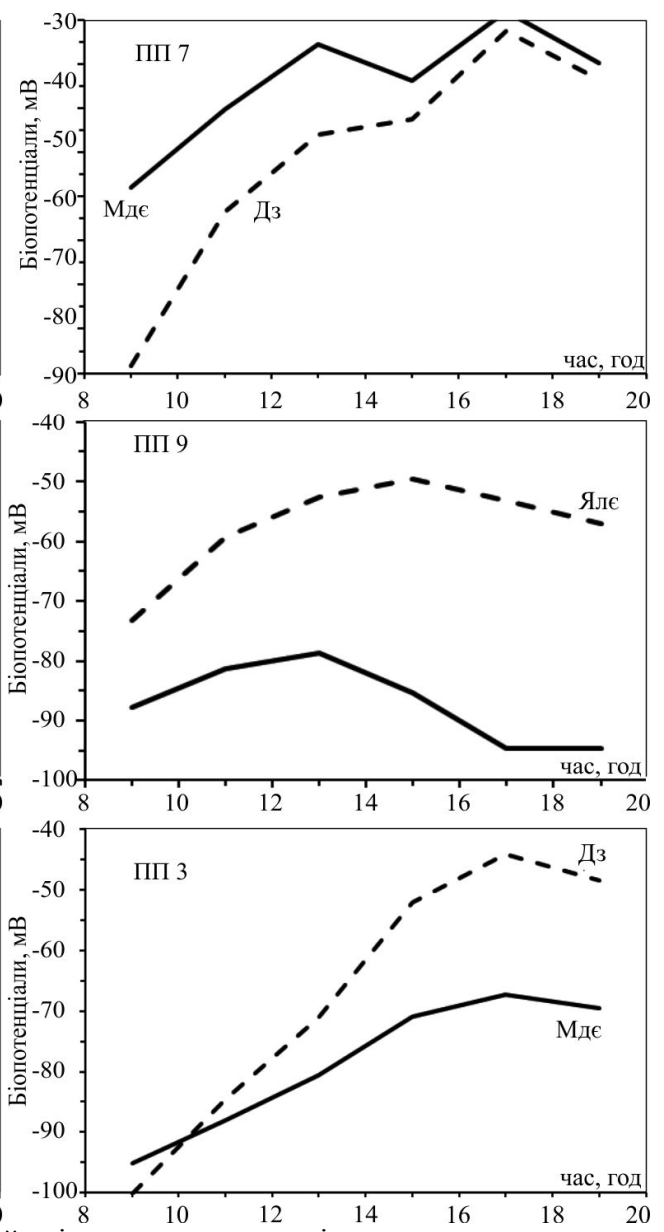

Рис. 2. Денна динаміка біоелектричних потенціалів кореневої шийки інших деревних видів

Табл. 2. Коефіцієнти кореляції між біометричними показниками дерев і мікрокліматичними показниками та біопотенціалами

\begin{tabular}{|c|c|c|c|c|c|c|}
\hline \multirow{2}{*}{$\begin{array}{c}\text { № пр. } \\
\text { пл. }\end{array}$} & \multirow{2}{*}{ Деревний вид } & \multicolumn{5}{|c|}{ Показник } \\
\hline & & висота & діаметр & температура повітря & вологість повітря & інтенсивність світла \\
\hline \multirow{2}{*}{15} & Мдє & 0,730 & 0,567 & 0,378 & $-0,357$ & 0,510 \\
\hline & $\mathrm{C}_{3}$ & 0,271 & 0,003 & 0,566 & $-0,635$ & 0,027 \\
\hline 13 & Мдє & 0,276 & 0,134 & 0,771 & $-0,704$ & 0,268 \\
\hline \multirow{2}{*}{14} & Мдє & 0,339 & 0,149 & 0,248 & $-0,564$ & 0,700 \\
\hline & $\mathrm{C}_{3}$ & 0,569 & 0,635 & 0,057 & $-0,123$ & 0,668 \\
\hline \multirow{2}{*}{6} & Мдг & 0,345 & 0,097 & 0,743 & $-0,855$ & 0,374 \\
\hline & Ялє & 0,461 & 0,228 & 0,792 & $-0,893$ & 0,475 \\
\hline 2 & Мдє & 0,548 & 0,372 & 0,215 & $-0,432$ & 0,067 \\
\hline 8 & Мдє & 0,343 & 0,259 & 0,134 & $-0,184$ & 0,432 \\
\hline 10 & Мдє & 0,073 & 0,619 & 0,433 & $-0,293$ & 0,220 \\
\hline \multirow{2}{*}{7} & Мдє & 0,333 & 0,250 & 0,844 & $-0,864$ & 0,060 \\
\hline & Д3 & 0,538 & 0,097 & 0,923 & $-0,963$ & 0,145 \\
\hline \multirow{2}{*}{1} & Мдє & 0,490 & 0,481 & 0,477 & $-0,240$ & 0,286 \\
\hline & Д3 & 0,120 & 0,247 & 0,850 & $-0,788$ & 0,416 \\
\hline \multirow{2}{*}{9} & Мдє & 0,120 & 0,331 & 0,769 & $-0,847$ & 0,087 \\
\hline & Ялє & 0,330 & 0,073 & 0,771 & $-0,856$ & 0,092 \\
\hline \multirow{2}{*}{16} & Мдє & 0,433 & 0,543 & 0,677 & $-0,732$ & 0,172 \\
\hline & Д3 & 0,320 & 0,764 & 0,594 & $-0,743$ & 0,216 \\
\hline \multirow{2}{*}{3} & Мдє & 0,120 & 0,331 & 0,769 & $-0,847$ & 0,087 \\
\hline & Д3 & 0,330 & 0,073 & 0,771 & $-0,856$ & 0,092 \\
\hline
\end{tabular}


3 табл. 2 видно, що між біометричними показниками модельних дерев різних деревних видів і середньоденними показниками біопотенціалів переважно спостерігаємо помірний і значний прямий кореляційний зв'язок. Вплив мікрокліматичних чинників на біоелектричну активність деревних видів у різних деревостанах проявляється по-різному. Більш тісною залежність денної зміни біопотенціалів виявлено від денної динаміки температури і вологості повітря, аніж від інтенсивності світла. Необхідно зазначити, що низькі показники коефіцієнтів кореляції між денною динамікою температури і вологості повітря, інтенсивністю світла та БЕП у деревних видів встановлено на ділянках 2, 8, 10 і дещо вищі на ділянці 14. На інших ділянках між цими показниками зазвичай переважають значні і високі значення кореляції.

\section{Висновки:}

1. Модрина європейська в умовах суборів і сугрудів характеризується нижчими абсолютними показниками БЕП кореневої шийки, порівняно з сосною звичайною, а в умовах грудів - вищими, порівняно 3 дубом звичайним. Встановлені відмінності між деревними видами зберігаються упродовж дня.

2. У модрини в мішаних молодняках і середньовікових деревостанах абсолютні значення БЕП виявились вищими, ніж у чистих.

3. Встановлено три типи денних біопотенціалограм, які характеризують динаміку проходження метаболічних процесів у деревних видів у деревостанах різних лісорослинних умов та видового складу.

4. Між біометричними показниками модельних дерев різних деревних видів і середньоденними показниками біопотенціалів переважно спостерігаємо помірний і значний прямий кореляційний зв'язок. Більш тісною залежність денної зміни біопотенціалів виявлено від денної динаміки температури і вологості повітря, аніж від інтенсивності світла.

\section{Перелік використаних джерел}

Aznieu, Yu. M., Rykhter, I. Je., \& Sarnatski, U. V. (1984). JElektrafiziialahichnyia pakazchyki drjeu va umovakh elniku charnichnaha. Vestsi AN BSSR. Ser. biialohichni navuki, 6, 15-18. [In Belarusian].

Kipkore, V. K., \& Maksimov, V. M. (1988). Vzaimosviaz bioelektricheskogo potentciala i kategorii sostoianiia derevev duba chereshchatogo v nasazhdeniiakh Uchebno-opytnogo leskhoza VLTI. Voronezh, 7 p. Dep. v TcBNTI leskhoz 12.07.88, № 711-lkh 88. Anot. $v$ RZh Lesovedenie i lesovodstvo, 4. [In Russian].
Kolovskii, R. A. (1973). Vliianie otnositelnoi vlazhnosti vozdukha na velichinu bioelektricheskogo potentciala drevesnykh rastenii. Lesovedenie, 6, 53-59. [In Russian].

Kolovskii, R. A. (1980). Bioelektricheskie potentcialy drevesnykh rastenii. Novosibirsk: Nauka, 176 p. [In Russian].

Krinitckii, G. T. (1984). Ob opredelenii zhiznennosti podrosta drevesnykh rastenii bioelektricheskim metodom. Lesnoi zhurnal, 4, 22-25. [In Russian].

Krinitckii, G. T. (1990). Bioelektricheskii metod opredeleniia zhiznesposobnosti drevesnykh rastenii na nachalnykh etapakh ontogeneza. Nauchno-proizvodstvennoe obedinenie kosmicheskikh issledovanii, 85, 61. [In Russian].

Krinitckii, G. T., \& Bondarenko, V. D. (1984). Issledovanie sviazi bioelektricheskikh potentcialov s osnovnymi fiziologicheskimi protcessami podrosta drevesnykh rastenii. Forestry, forestry, paper and woodworking industry, 15, 15-18. [In Russian].

Krynytskyi, H. T. (1992). Pro metodyku vykorystannia elektrofiziolohichnykh pokaznykiv dlia vyznachennia zhyttiezdatnosti derevnykh roslyn. Proceedings of the Forestry Academy of Sciences of Ukraine, 23, 3-10. [In Ukrainian].

Krynytskyi, H. T. (1993). Morfofiziolohichni osnovy selektsii derevnykh porid. Abstract of Doctoral Dissertation for Biology Sciences (06.03.01 - Forest Crops and Phytomelioration), (03.00.12 Plant physiology). Kyiv, 46 p. [In Ukrainian].

Krynytskyi, H. T., \& Zaika, V. K. (1995). Vplyv osoblyvostei formuvannia molodykh pivsibsovykh nasadzhen sosny zvychainoi na bioelektrychnu aktyvnist derev. Scientific Bulletin of UNFU, 4, 153-160. [In Ukrainian].

Rutkovskii, I. V. (1965). Elektrofiziologicheskii metod opredeleniia sostoianiia drevesnykh rastenii. Herald of agricultural science, 4, 35-38. [In Russian].

Rutkovskii, I. V. (1973). Bioelektricheskaia aktivnost topolei raznogo fiziologicheskogo sostoianiia v sutochnom i sezonnom ritmakh. Lesovedenie, 1, 51-57. [In Russian].

Rutkovskii, I. V., \& Kishenkov, F. V. (1980). Primenenie elektrofiziologicheskikh metodov v lesovyrashhivanii. Moscow: TcBNTI Gosleskhoza, 41 p. [In Russian].

Rybak, Yu. L., \& Zaika, V. K. (2013). Zmina elektrofiziolohichnoi aktyvnosti u derev sosny zvychainoi, urazhenykh shiutte zvychainym. Scientific Bulletin of UNFU, 23(2), 90-96. [In Ukrainian].

Salna, L. A. (1964). Izmenenie bioelektricheskikh potentcialov rastenii pod vliianiem vneshnikh uslovii. Fiziko-khimicheskie osnovy proiskhozhdeniia biopotentcialov, (pp. 165-168). Moscow: Nauka, 360 p. [In Russian].

Shevernozhuk, R. G. (1968). Bioelektricheskaia aktivnost eli i metodika ee izmereniia. Lesnoi zhurnal, 4, 36-39. [In Russian].

Zaika, V. K., Kerimov, E. I., \& Ivanytskyi, R. S. (2016). Poshyrennia ta rist modryny yevropeiskoi $\mathrm{v}$ umovakh Kremenetskoho horbohiria. Proceedings of the Forestry Academy of Sciences of Ukraine, 14, 45-51. [In Ukrainian].

\title{
Э. И. Керимов ${ }^{1}$, В. К. Заика \\ ${ }^{1}$ Кременеикий лесотехнический колледж, с. Белокриница, Украина \\ ${ }^{2}$ Национальный лесотехнический университет Украины, г. Львов, Украина
}

\section{БИОЭЛЕКТРИЧЕСКИЕ ПОТЕНЦИАЛЫ ЛИСТВЕННИЦЫ ЕВРОПЕЙСКОЙ В ДРЕВОСТОЯХ КРЕМЕНЕЦКОГО ХОЛМОГОРЬЯ}

\begin{abstract}
Исследованы биоэлектрические потенциалы лиственницы европейской, дуба черешчатого, ели европейской и сосны обыкновенной, которые формируют древостои в различных типах лесорастительных условий Кременецкого холмогорья. Возраст древостоев составляет 12-109 лет. Долевое участие лиственницы в их составе колеблется в пределах 1-10 единиц. Лиственница европейская в условиях суборов и сугрудов характеризуется более низкими абсолютными показателями БЭП корневой шейки по сравнению с сосной обыкновенной, а в условиях грудов - более высокими по сравнению с дубом черешчатым и елью европейской. Установленные различия между древесными видами по величине БЭП сохраняются в течение дня. Различия между лиственницей и дубом по абсолютным показателям биопотенциалов усиливаются во второй половине дня. У лиственницы в смешанных молодняках и средневозрастных древостоях абсолютные значения БЭП оказались выше, чем в чистых древостоях. Установлено три типа дневных биопотенциалограмм, характеризующих динамику прохождения метаболических процессов древесных видов в древостоях различных лесорастительных условий и видового состава. Между биометрическими показателями модельных деревьев различных древесных видов и среднедневными показателями биопотенциалов преимущественно наблюдается умеренная и значительная прямая корреляционная связь. Более тесная зависимость дневной динамики биопотенциалов обнаружена от дневной динамики температуры и влажности воздуха, чем от днев-
\end{abstract}


ной динамики интенсивности света. Между влажностью воздуха и биоэлектрическими потенциалами существует обратная корреляционная связь.

Ключевые слова: биоэлектрические потенциалы; лиственница европейская; древостой; дневные биопотенциалограммы; корреляционная связь.

E. I. Kerimov' ${ }^{1}$ V. K. Zaika ${ }^{2}$

${ }^{1}$ Kremenetskiy Forestry College, Bilokrynytsya, Ukraine

${ }^{2}$ Ukrainian National Forestry University, Lviv, Ukraine

\section{BIOELECTRIC POTENTIALS OF EUROPEAN LARCH IN THE STANDS OF THE KREMENETS HILL AREA}

Bioelectric potentials (BEP) of European larch, common oak, Norway spruce and Scotch pine which form forest stands in different types of site conditions of the Kremenets Hill area are investigated. The age of the stands is supposed to be 12-109 years. The share of larch in their composition varies within 1-10 units. A high-ohmic biopotential meter and non-polarizing silver-chloride electrodes were used to measure the BEP. The measurement of the daily dynamics of biopotentials of the trees was carried out at the level of the root collar relative to the ground in the cloudless or slightly cloudy weather. For conducting research in the stand, we selected 10-20 model trees of each species with varying growth rate. In the young stands, the average daily values for the BEP of the European larch root collar are $-45.7--65.0$, in the middle-aged stands $--71.8--87.0$, and in the overmature stands - $-48.6--$ $59.3 \mathrm{mV}$. In the conditions of fairly infertile pine site type and fairly fertile site type, European larch is characterized by lower absolute BEP indexes of the root collar as compared to Scotch pine, and in the conditions of fertile site type, it is characterized by higher index values, as compared to common oak and Norway spruce. The differences found between the tree species are preserved throughout the day. The differences between larch and oak in terms of absolute index values of biopotentials become greater in the afternoon. The BEP absolute values for larch in young- and middle-aged stands were found to be higher than in pure stands. A decrease was revealed in bioelectric activity of larch and other tree species with decreasing nutrient status of soils. Three types of daily biopotential graphs have been established that characterize the dynamics of metabolic processes occurring in the tree species in forest stands of different site types and species composition. The first type is characterized by a slight decrease in the absolute indexes of biopotentials in the first half of the day and insignificant growth in the second half. The second type is noted for a rapid decline in the index values by the middle of the day and then by a sharp increase in its second half. The third type is characterized by an intense decrease in the BEP of the root collar throughout the day. Between biometric parameters of model trees of different tree species and the average daily values of biopotential, moderate and significant direct correlation relationships are observed. It is found that there is a closer dependence of the daily change in biopotentials on the daily dynamics of the air temperature and humidity, rather than the intensity of illumination. There is a reciprocal correlation between the air humidity and bioelectric potentials.

Keywords: bioelectric potentials; European larch; forest stand; daily biopotential graphs; correlation relationship. 